\title{
STUDI PEMBELAJARAN MENGGUNAKAN MODUL DAN WALL CHART PADA KOMPETENSI SISTEM KOPLING
}

\author{
Musthafa Kamal $^{1}$, Ono Wiharna ${ }^{2}$, Mumu Komaro ${ }^{3}$ \\ Departemen Pendidikan Teknik Mesin \\ Universitas Pendidikan Indonesia \\ Jl. Dr. Setiabudhi No. 207 Bandung 40154 \\ musthafakamal33@yahoo.com
}

\begin{abstract}
ABSTRAK
Tujuan dilaksanakannya penelitian ini adalah untuk mengetahui hasil belajar siswa serta peningkatan hasil belajarnya, setelah menggunakan modul dan wall chart pada kompetensi sistem kopling. Penelitian ini dilakukan dengan menggunakan metode eksperimen true experimental design dengan bentuk desain pre-test posttest control group design. Populasi dalam penelitian ini adalah siswa kelas XI SMK Negeri Bantarkalong Tasikmalaya teknik kendaraan ringan yang berjumlah 4 kelas dengan jumlah siswa sebanyak 125 orang. Sampel penelitian dibagi menjadi dua kelas yaitu kelas eksperimen yang menggunakan modul dan kelas kontrol yang menggunakan wall chart. Instrumen yang digunakan pada penelitian ini yaitu pre test yang dilaksanakan sebelum siswa melaksanakan proses pembelajaran dan post test setelah siswa melaksanakan proses pembelajaran. Kedua soal tes tersebut digunakan untuk melihat peningkatan hasil belajar siswa. Hasil penelitian menunjukkan bahwa rata-rata hasil belajar siswa pada skor post test setelah menggunakan modul sebesar 75,39 dan rata-rata hasil belajar pada skor post testsiswa setelah menggunakan wall chartsebesar 72,14. Peningkatan hasil belajar siswa yang menggunakan modul sebesar 57\% dan peningkatan hasil belajar menggunakan wall chart sebesar $49 \%$. Kesimpulan penelitian ini yaitu ata-rata hasil belajar siswa setelah menggunakan modul berada pada kategori sedang dengan peningkatan hasil belajar berada pada kategori sedang juga; dan ata-rata hasil belajar siswa setelah menggunakan wall chart berada pada kategori rendah, dengan peningkatan hasil belajar berada pada kategori sedang.
\end{abstract}

Kata Kunci: modul, wall chart, hasil belajar, kopling

\section{PENDAHULUAN}

Pendidikan merupakan sektor yang paling utama bagi setiap bangsa untuk mewujudkan sumber daya manusia yang berkualitas. Pendidikan nasional yang berdasarkan Pancasila dan Undang-Undang Dasar Negara Republik Indonesia Tahun 1945 berfungsi mengembangkan kemampuan dan membentuk watak serta peradaban bangsa yang bermartabat dalam rangka mencerdaskan kehidupan bangsa, sebagaimana yang tercantum dalam UU No. 20 tahun 2003 tentang Sistem Pendidikan Nasional Pasal 3 menyatakan bahwa: pendidikan nasional berfungsi mengembangkan kemampuan serta membentuk watak dan peradaban bangsa yang bermartabat dalam rangka mencerdaskan kehidupan bangsa, bertujuan untuk mengembangkan potensi peserta didik agar menjadi manusia yang beriman dan bertakwa kepada Tuhan yang Maha Esa, berakhlak mulia, sehat, berilmu, cakap, kreatif mandiri, menjadi warga negara yang demokratis secara bertanggung jawab.

\footnotetext{
${ }^{1}$ Mahasiswa Departemen Pendidikan Teknik Mesin FPTK UPI

${ }^{2}$ Dosen Departemen Pendidikan Teknik Mesin FPTK UPI

${ }^{3}$ Dosen Departemen Pendidikan Teknik Mesin FPTK UPI
} 
Undang-undang tersebut menekankan pada kualitas sumber daya manusia yang diharapkan mampu mengikuti perkembangan zaman, sehingga secara tidak langsung sistem pendidikan Indonesia harus ditingkatkan mutunya secara bertahap, berkesinambungan dan mengoptimalkan peran serta fungsi pendidikan sebagai wadah pembentukan sumber daya manusia. Oleh karena itu, mengembangkan isi, bentuk dan penyelenggaraan pendidikan yang lebih baik diharapkan pendidikan di Indonesia dapat menghasilkan sumber daya manusia yang lebih berkualitas dan mandiri. Sekolah Menengah Kejuruan (SMK) merupakan lembaga pendidikan formal dimana lulusannya dipersiapkan untuk memasuki dunia kerja dan memiliki kemampuan yang sesuai dengan kebutuhan industri/perusahaan. Sekolah bukan saja mengharapkan siswa yang mampu, cakap dan terampil dalam keahlian tertentu, tetapi yang paling terpenting mereka senantiasa mau giat belajar dan berkeinginan untuk mencapai hasil belajar yang optimal. Salah satu indikator pendidikan berkualitas adalah perolehan nilai hasil belajar siswa (Supraptama, 2001). Nilai hasil belajar siswa lebih ditingkatkan apabila pembelajarannya berlangsung secara efektif dan efisien, dan ditunjang oleh tersedianya sarana dan prasarana pendukung serta kecakapan guru dalam pengelolaan kelas dan penguasaan materi yang cukup memadai.

Hasil pembelajaran yang ingin dicapai dari setiap proses pembelajaran adalah materi yang disampaikan oleh guru dapat sepenuhnya dimengerti oleh siswa, serta nilai yang diperoleh oleh siswa berada diatas nilai KKM yang telah ditentukan oleh sekolah. Kenyataannya dari data hasil obeservasi awal yang dilakukan oleh peneliti di SMK Negeri Bantarkalong Tasikmalaya, hasil belajar siswa pada mata pelajaran produktif chasis kompetensi kopling masih rendah.

Siswa yang mendapatkan nilai dibawah 75 jumlahnya masih banyak, sedangkan seorang siswa dinyatakan lulus apabila nilai evaluasi pada akhir pembelajaran mendapatkan nilai diatas 75 . Sesuai dengan kriteria ketuntasan minimal (KKM) untuk mata pelajaran produktif di SMK Negeri Bantarkalong yaitu sebesar 75 (dalam skala 0100). Proses belajar siswa dipengaruhi oleh beberapa faktor yang dikelompokan menjadi 3 bagian, yaitu raw input, environment input dan instrumental input. Faktor yang pertama adalah raw input yang meliputi minat, bakat, pengalaman, tingkat perkembangan dan tingkat kecerdasan siswa. Faktor kedua environmentinput yang meliputi aturan kelas, waktu iklim sekolah dan lingkungan sekolah. Faktor ketiga adalah instrumental input yang meliputi kurikulum, media pembelajaran, alat dan bahan. 
Instrumental input dalam proses pembelajaran salah satunya adalah bahan ajar. Bahan ajar memiliki fungsi untuk menyampaikan pesan pembelajaran serta memperjelas penyajian pesan, mengatasi keterbatasan ruang dan waktu dan memungkinkan interaksi belajar mengajar yang lebih bervariasi dan bergairah. Pemanfaatan bahan ajar tersebut diharapkan akan membawa pengaruh positif terhadaphasil belajar siswa agar tercapai tujuan pembelajaran. Hasil belajar yang baik dapat diperoleh apabila guru menggunakan bahan ajar yang inovatif serta mudah menarik perhatian siswa. Alat pelajaran yang lengkap dan tepat akan memperlancar penerimaan bahan pelajaran yang diberikan kepada siswa, alat yang membantu lancarnya belajar siswa seperti buku diperpustakaan, laboratorium atau media-media lain (Slameto, 2010).

Pemerolehan hasil belajar melalui indera pandang sekitar 75\%, melalui indera dengar sekitar 13\% dan melalui indera lainnya sekitar 12\% (Sadiman, 2008). Berdasarkan hal tersebut maka seorang guru harus berupaya menampilkan rangsangan yang dapat diproses oleh indera pandang. Rangsangan tersebut disusun menjadi sebuah bahan ajar sehingga dapat mengembangkan potensi kecerdasan siswa dari segi visual. Kecerdasan visual memungkinkan siswa untuk merasakan bayangan eksternal dan internal, melukiskan kembali, merubah, atau memodifikasi bayangan, dan menghasilkan atau menguraikan informasi grafik. Kecerdasan ini dapat dimiliki oleh siswa apabila guru menyusun dengan baik sebuah bahan ajar sesuai dengan potensi kecerdasan siswa tersebut.

Berdasarkan pengalaman dan pengamatan pada saat melaksanakan PPL di SMK Negeri Bantarkalong Tasikmalaya tahun ajaran 2013/2014, proses pembelajaran siswa pada mata pelajaran produktif khususnya teori dinilai belum maksimal. Guru hanya menjelaskan materi dengan metode ceramah saja tanpa menggunakan media pembelajaran yang dapat membantu pemahaman siswa. Selain itu juga disebabkan keterbatasan jumlah alat praktik yang bisa dijadikan sebagai bahan demonstrasi.

Jurusan Teknik Kendaraan Ringan di sekolah ini hanya memiliki satu buah infokus, padahal dalam satu hari ada 3-4 rombongan belajar yang melaksanakan proses pembelajaran mata pelajaran produktif. Selain itu pada hari-hari tertentu di daerah tersebut masih dilakukan pemadaman listrik secara bergiliran, sehingga penggunaan infokuspun tidak bisa dilaksanakan.

Banyak cara untuk mengatasi permasalahan diatas sehingga proses pembelajaran dapat berjalan dengan baik dan hasil belajar yang maksimal, antara lain dengan penggunaan media pembelajaran yang efektif dan penerapan metode-metode pembelajaran yang sesuai. Sehubungan dengan itu, peneliti mencoba meningkatkan hasil belajar siswa 
dengan melaksanakan pengulangan pembelajaran dengan menggunakan media pembelajaran yang berbeda. Pembelajaran yang menggunakan bahan ajar modul dan pembelajaran yang menggunakan bahan ajar wall chart pada kompetensi sistem kopling. Sehingga nanti dapat diketahui gambaran hasil belajar dari masing-masing bahan ajar. Penggunaan modul Auto Cad berpengaruh terhadap hasil belajar siswa, menyimpulkan bahwa rata-rata peningkatan hasil belajar siswa yang menggunakan modul lebih tinggi dibandingkan dengan siswa yang tidak menggunakan modul. Penggunaan wall chart dalam pembelajaran, menunjukan penggunaan bahan ajar wall chart dapat meningkatkan hasil belajar siswa (Prihastuti, 2011).

\section{METODE PENELITIAN}

Metode yang digunakan dalam penelitian ini adalah metode eksperimen dengan desain penelitian true experimental design. Selama melakukan eksperimen, siswa merupakan objek penelitian yang tetap mengikuti pelajaran dalam kelas seperti biasa. Desain penelitian true experimental design, memiliki beberapa macam, peneliti memilih tipe pretest-posttest control group design, yaitu kedua kelompok dipilih secara random, kemudian diberi pre test untuk mengetahui keadaan awal adakah perbedaan antara kelompok eksperimen dan kelompok kontrol. Kedua kelompok diberikan pre test dan post test dengan soal yang setara untuk mengetahui perbedaan hasil belajar setelah diberikan perlakuan/treatment.

\section{HASIL PENELITIAN}

Hasil belajar siswa diperoleh setelah melakukan proses pembelajaran yang diukur melalui tes. Tes ini dilakukan dua kali yang pertama pre test (tes sebelum melakukan pembelajaran) dan post test (tes setelah melakukan proses pembelajaran). Kemampuan awal siswa sebelum melakukan proses pembelajaran memiliki nilai rata-rata sebesar 41,42, nilai ini belum memenuhi KKM (75) yang telah ditetapkan oleh sekolah. Setelah dilakukan pembelajaran menggunakan bahan ajar modul, nilairata-rata siswa mengalami peningkatan menjadi 75,39. Nilai ini berada di atas KKM (75) masuk dalam kategori sedang.

Hasil belajar siswa kelas eksperimen, hasil belajar siswa kelas kontrol diperoleh setelah melakukan proses pembelajaran yang diukur melalui tes. Tes ini dilakukan dua kali yang pertama pre test (tes sebelum melakukan pembelajaran) dan post test (tes setelah melakukan proses pembelajaran). 
Kemampuan awal siswa sebelum melakukan proses pembelajaran memiliki nilai rata-rata sebesar 44,46, nilai ini belum memenuhi KKM (75) yang telah ditetapkan oleh sekolah. Setelah dilakukan pembelajaran menggunakan bwall chart nilai rata-rata siswa mengalami peningkatan menjadi 72,14, tetapi belum memenuhi KKM (75). Nilai rata-rata tersebut berada pada kategori kurang.

Peningkatan hasil belajar siswa diukur dengan perhitungan $\mathrm{N}$-Gain yang diperoleh dari perhitungan data pre test dan post test. Pembelajaran menggunakan wall chart menghasilkan skor rata-rata pre test sebesar 8,85, skor rata-rata post test sebesar 14,25 dan skor rata-rata N-Gainnya sebesar 0,49 atau 49\%, yang berada pada kategori sedang. Hasil belajar pada pembelajaran menggunakan modul menghasilkan skor post test yang lebih tinggi dibandingkan pembelajaran menggunakan wall chart. Skor rata-rata pre test sebesar 8,28 , skor rata-rata post test sebesar 15,03 dengan skor rata-rata $N$-Gain sebesar 0,57 atau 57\%, sama dengan pembelajaran menggunakan wall chart. Pembelajaran menggunakan modul rata-rata skor N-Gainnya berada pada kategori sedang.

Kemampuan awal siswa sebelum memperoleh materi pelajaran, khususnya kompetensi sistem kopling. Kemampuan awal siswa pada kelas kontrol lebih tinggi dibandingkan dengan kelas eksperimen. Rata-rata kemampuan awal pada kelas kontrol sebesar 44,4, sedangkan pada kelas eksperimen sebesar 41,4. Data post test memberikan gambaran kemampuan akhir siswa setelah melakukan pembelajaran. Data post test ini diperoleh dari tes tertulis dengan jenis tes dan jumlah soal yang setaradenganpre test. Ratarata kemampuan penguasaan materi pada kelas eksperimen lebih tinggi dibandingkan dengan kelas kontrol. Rata-rata kemampuan siswa pada kelas eksperimen (pembelajaran dengan bahan ajar modul) didapatkan nilai rata-rata sebesar 82,5, sedangkan rata-rata kemampuansiswa pada kelas kontrol (pembelajaran dengan wall chart) didapatkan nilai rata-rata sebesar 72,1 .

Hasil perhitungan dengan menggunakan data dari pre test dan post test. Data $N$ Gain menunjukkan peningkatan kemampuan siswa setelah mengikuti pembelajaran. Ratarata peningkatan penguasaan kompetensi sistem kopling. Pada kelas ekperimen nilai $\mathrm{N}$ Gain lebih tinggi dibandingkan kelas kontrol. Pada kelas kontrol didapatkan rata-rata skor $N$-Gain sebesar 0,49 yang berada pada kategori sedang, sedangkan rata-rata $N$-Gain pada kelas eksperimen sebesar 0,57 yang berada pada kategori sedang pula. 


\section{PEMBAHASAN}

Hasil belajar siswa pada pembelajaran yang menggunakan modul memperoleh nilai rata-rata post test sebesar 75,39. Hasil interpretasi hasi belajar, nilai ini berada pada kategori kurang, akan tetapi walaupun demikian nilai ini telah memenuhi standar nilai KKM. Pembelajaran menggunakan modul menghasilkan skor rata-rata $\mathrm{N}$-Gain sebesar 0,57 atau peningkatan hasil belajarnya sebesar 57\%, yang berada pada kategori sedang. Modul memiliki informasi yang dapat dipelajari oleh siswa sesuai kebutuhan, minat dan kecepatan masing-masing (Susilana dan Riyana, 2008). Berdasarkan penjelasan tersebut, modul memiliki beberapa aspek yang dapat meningkatkan hasil belajar siswa.

Pembelajaran menggunakan modul lebih bersifat self instructional. Setiap siswa diberi modul kemudian modul tersebut dipelajari masing-masing oleh siswa tanpa guru menjelaskan secara rinci setiap materi. Guru hanya menjelaskan materi yang tidak dimengerti oeh siswa yang ditanyakan kepada guru. Apabila merujuk pada konsep bahwa belajar melalui indra pandang sekitar $75 \%$. Hasil peneitian ini belum sesuai dengan konsep tersebut karena peningkatan hasil belajar pada penelitian ini hanya sebesar 57\%. Walaupun demikian, pembelajaran menggunakan modul ini dapat meningkatkan hasil belajar siswa secara signifikan. Nilai rata-rata siswa pada saat post test di atas nilai KKM.

Hasil belajar siswa pada pembelajaran yang menggunakan modul memperoleh nilai rata-rata post test sebesar 72,14, apabila melihat tabel interpretasi hasil belajar, nilai ini berada pada kategori kurang dan nilai ini belum memenuhi standar nilai KKM. Pembelajaran menggunakan wall chart menghasilkan skor rata-rata $N$-Gain sebesar 0,49 atau peningkatan hasil belajarnya sebesar $49 \%$, yang berada pada kategori sedang.

Melihat sebuah foto/gambar lebih tinggi maknanya daripada membaca atau mendengar. Melalui membaca yang diingat $10 \%$, dari mendengar yang diingat $20 \%$ dan dari melihat yang diingat $30 \%$. Pembelajaran menggunakan wall chart yang dapat diingat hanya sebesar $50 \%$ yaitu dari mendengar dan melihat. Pada pembelajaran ini siswa hanya memperhatikan gambar-gambar yang berada pada wall chart, kemudian guru menjelaskan setiap materi pada setiap gambar tersebut (Supraptama 2001).

Setelah melakukan proses pembelajaran dengan dua penggunaan bahan ajar yang berbeda, peneliti menemukan beberapa kelebihan dan kekurangan dalam penggunaan bahan ajar tersebut. Penggunaan modul lebih efektif digunakan, karena pemaparan materi yang terkandung didalam modul sudah cukup jelas, tanpa harus di jelaskan satu persatu dan menghasilkan nilai akhir pembelajaran yang cukup baik. Akan tetapi, dilihat dari segi 
ekonomi, penyediaan bahan ajar modul tidak murah, dikarenakan guru harus menyediakan modul sesuai dengan jumlah siswa yang akan mengikuti proses pembelajaran.

Pembelajaran menggunakan wall chart cukup praktis dilaksanakan dan lebih ekonomis. Guru hanya tinggal menyediakan gambar-gambar yang akan ditempelkan di depan ruang kelas. Pengetahuan dan pemahaman guru tentang materi yang akan disampaikan harus sepenuhnya dikuasai, karena pada pembelajaran ini guru menjelaskan materi secara rinci.

\section{KESIMPULAN}

Kesimpulan penelitian ini, sebagai berikut: hasil belajar siswa yang menggunakan modul memperoleh rata-rata nilai post test sebesar 75,4. Hasil belajar siswa yang menggunakan wall chart memperoleh rata-rata nilai post test sebesar 72,2. Peningkatan hasil belajar pada kelas eksperimen (pembelajaran menggunakan modul) sebesar 0,57 atau 57\% dan peningkatan hasil belajar pada kelas kontrol (pembelajaran menggunakan wall chart) sebesar 0,49 atau 49\%. Peningkatan hasil belajar pada kedua pembelajaran ini berada pada kategori sedang.

\section{DAFTAR PUSTAKA}

Depadiknas. (2003). Pedoman Pengembangan bahan Ajar. Jakarta: Depdiknas.

Prihastuti, E. N. (2011). Keefektifan penggunaan media wall chart (bagan dinding) dalam meningkatkan kemampuan menulis karangan argumentasi siswa kelas x SMA negeri 1 seyegan sleman. (Jurnal). Universitas Negeri Yogyakarta, Yogyakarta [5 September 2015].

Sadiman, S.A. (2008). Media Pendidikan. Jakarta: Raja Garafindo Persada.

Slameto. (2010). Belajar dan faktor-faktor yang mempengaruhinya. Jakarta: Rineka Cipta

Supraptama. (2001). Meningkatkan Motivasi Belajar Siswa dalam Mata Pelajaran Geografi Melalui Pendekatan Cooperative Learning. Bandung: Buletin Pelangi Pendidikan.

Susilana dan Riyana. (2008). Media Pembelajaran. Bandung: Jurusan Kurtekpend FIP UPI. 